\title{
OVIDUCT SECRETION IN THE COW
}

\author{
D. GARLSON, D. L. BLACK AND G. R. HOWE \\ Laboratory for Reproductive Physiology, Department of Veterinary and Animal Sciences, \\ University of Massachusetts, Amherst, Massachusetts, U.S.A.
}

\section{(Received 23rd October 1969)}

Little is known regarding the physiological rôle of oviduct fluid on ova and spermatozoa in the reproductive tract. VanDemark (1958) and Bishop (1961) suggested that luminal fluids may be an important transport and nutrient medium for the gametes; others felt that oviduct secretions influenced sperm activity (Olds \& VanDemark, 1957a) or aided the capacitation process (Austin, 1951: Chang, 1951). Oviduct fluid has been collected from several species by ligation of portions of the genital tract (Blandau, Jensen \& Rumery, 1958), flushing portions of the tract (Heap, 1962), expressing the contents of tracts after slaughter (Olds \& VanDemark, 1957b), and cannulation of portions of the tract in living animals (Clewe \& Mastroianni, 1960; Restall, 1966). To our knowledge, oviduct secretion has never been continuously collected throughout the oestrous cycle and an attempt was made to determine whether the volume, protein content, or glucose content of oviduct fluid varied during the oestrous cycle.

Cows of small size were chosen for this experiment because the reproductive tract was more accessible at surgery. Surgery was performed at mid-cycle, either under local anaesthesia (infusion of Xylocaine), or general anaesthesia (Equithesin). In both cases, an incision was made in the flank area and the uterus and oviduct were drawn as close as possible to the opening. The ovarian end of the oviduct was located and one end of a $60-\mathrm{cm}$ long silastic cannula (ID $0.10 \mathrm{~cm}$, OD $0.20 \mathrm{~cm}$ ) was inserted to a depth of $15 \mathrm{~mm}$. Two collars were placed on the end of the cannula, which was held in place by two Supramid sutures; the uterine end of the oviduct was ligated with one Supramid suture to prevent flow of oviduct fluid into the uterus. A small amount of air was injected into the cannula, which was considered patent if the oviduct distended. The cannula was then brought out through the incision and the animal was given 1 million units of procaine penicillin in oil daily for 4 days.

The collection device was contained in a 3- $\times 4$-in. aluminium cassette attached to the animal with four sutures. The cannula was inserted through a plastic disc at the surface of the skin and several sutures tied around it to prevent the cannula from slipping through the plastic disc and into the body cavity. The cannula entered a plastic vial within the cassette and the vial was changed daily. The fluid was left in the vial and frozen; the volumes were later measured with a $1-\mathrm{ml}$ tuberculin syringe.

For analysis, the fluid was pooled on a 4-day basis with respect to oestrus, e.g. a sample labelled +1 would include fluid collected on the 1st day of oestrus 
and the following 3 days, a sample labelled -1 would include fluid collected on the 4 days preceding oestrus, a sample labelled +2 would include fluid collected from the 4 th to the 7 th day inclusive after oestrus, etc.

TABLE 1

OVIDUCT SECRETION VOLUME IN THE cow

\begin{tabular}{|c|c|c|}
\hline $\begin{array}{l}\text { Day of } \\
\text { oestrous } \\
\text { cycle }\end{array}$ & $\underset{177}{\text { Animal no. }}$ & $\begin{array}{l}\text { Animal no. } \\
239\end{array}$ \\
\hline $\begin{array}{c}\text { Oestrus } \\
1 \\
2 \\
3 \\
4 \\
5 \\
6 \\
7 \\
8 \\
9 \\
10 \\
11 \\
12 \\
13 \\
14 \\
15 \\
16 \\
17 \\
18 \\
19 \\
20 \\
21 \\
22 \\
23\end{array}$ & $\begin{array}{l}1.17 \pm 1.03 \\
1.22 \pm 0.42 \\
0.69 \pm 0.21 \\
0.59 \pm 0.65 \\
0.45 \pm 0.18 \\
0.35 \pm 0.13 \\
0.43 \pm 0.25 \\
0.39 \pm 0.17 \\
0.39 \pm 0.26 \\
0.97 \pm 0.08 \\
0.48 \pm 0.52 \\
0.22 \pm 0.25 \\
0.13 \pm 0.05 \\
0.27 \pm 0.09 \\
0.15 \pm 0.01 \\
0.25 \pm 0.06 \\
0.21 \pm 0.08 \\
0.35 \pm 0.08 \\
0.25 \pm 0.17 \\
0.24 \pm 0.26 \\
0.20 \pm 0.09 \\
0.25 \pm 0.11 \\
0.07 \pm 0.07 \\
0.27 \pm 0.34\end{array}$ & $\begin{array}{c}1.54 \pm 0.36 \\
1.71 \pm 0.70 \\
1.13 \pm 0.65 \\
0.91 \pm 0.17 \\
0.32 \pm 0.10 \\
0.39 \pm 0.12 \\
0.30 \pm 0.02 \\
0.33 \pm 0.07 \\
0.33 \pm 0.08 \\
0.34 \pm 0.11 \\
0.18 \pm 0.07 \\
0.33 \pm 0.16 \\
0.21 \pm 0.94 \\
0.21 \pm 0.03 \\
0.18 \pm 0.08 \\
0.42 \pm 0.36 \\
0.29 \pm 0.03 \\
0.19 \pm 0.12 \\
0.41 \pm 0.10 \\
0.70 \pm 0.61 \\
= \\
=\end{array}$ \\
\hline
\end{tabular}

Oviduct secretion in $\mathrm{ml} / 24 \mathrm{hr}$ (Mean of three cycles \pm S.E.)

TABLE 2

PROTEIN AND GLUCOSE CONTENT OF COW OVIDUCT FLUID DURING THE OESTROUS CYCLE

\begin{tabular}{|c|c|c|c|c|c|c|c|c|}
\hline & $\begin{array}{c}\text { Animal } \\
\text { no. }\end{array}$ & +1 & +2 & $\begin{array}{l}\text { Period o } \\
\quad+3\end{array}$ & $\begin{array}{c}\text { collection } \\
-3\end{array}$ & -2 & -1 & $\begin{array}{c}\text { Mean } \\
\pm S . D .\end{array}$ \\
\hline Mean volume & $\begin{array}{l}239 \\
177\end{array}$ & $\begin{array}{l}5 \cdot 29 \\
3 \cdot 18\end{array}$ & $\begin{array}{l}1.21 \\
1.63\end{array}$ & $\begin{array}{l}1 \cdot 19 \\
1 \cdot 19\end{array}$ & $\overrightarrow{0.83}$ & $\begin{array}{l}1.02 \\
1.05\end{array}$ & $\begin{array}{l}1.33 \\
0.79\end{array}$ & $=$ \\
\hline Mean protein $(\mathrm{mg} / \mathrm{ml})$ & $\begin{array}{l}239 \\
177\end{array}$ & $\begin{array}{l}0.70 \\
1.54\end{array}$ & $\begin{array}{l}0.63 \\
1.59\end{array}$ & $\begin{array}{l}0.65 \\
1.94\end{array}$ & $\overline{1 \cdot 40}$ & $\begin{array}{l}1 \cdot 16 \\
1.46\end{array}$ & $\begin{array}{l}0.97 \\
1.55\end{array}$ & $\begin{array}{l}0.83 \pm 0.23 \\
1.58 \pm 0.19\end{array}$ \\
\hline Mean total protein (mg) & $\begin{array}{l}239 \\
177\end{array}$ & $\begin{array}{l}3 \cdot 74 \\
5 \cdot 26\end{array}$ & $\begin{array}{l}0.79 \\
2 \cdot 60\end{array}$ & $\begin{array}{l}0.90 \\
1.90\end{array}$ & $\overline{1 \cdot 11}$ & $\begin{array}{l}1.23 \\
1.41\end{array}$ & $\begin{array}{l}0.99 \\
1 \cdot 17\end{array}$ & $\begin{array}{l}1.53 \pm 0.13 \\
2 \cdot 24 \pm 0.50\end{array}$ \\
\hline Mean glucose $(\mu \mathrm{g} / \mathrm{ml})$ & $\begin{array}{l}239 \\
177\end{array}$ & $\begin{array}{r}16 \cdot 50 \\
9.24\end{array}$ & $\begin{array}{r}18.03 \\
9.69\end{array}$ & $\begin{array}{r}15 \cdot 88 \\
9 \cdot 51\end{array}$ & $\overline{10 \cdot 15}$ & $\begin{array}{l}16 \cdot 29 \\
10 \cdot 17\end{array}$ & $\begin{array}{r}16 \cdot 15 \\
9 \cdot 54\end{array}$ & $\begin{array}{r}16 \cdot 57 \pm 0.85 \\
9 \cdot 72 \pm 1 \cdot 18\end{array}$ \\
\hline Mean total glucose $(\mu \mathrm{g})$ & $\begin{array}{l}239 \\
177\end{array}$ & $\begin{array}{l}87 \cdot 40 \\
29.52\end{array}$ & $\begin{array}{l}21 \cdot 86 \\
15.98\end{array}$ & $\begin{array}{l}20 \cdot 76 \\
11 \cdot 80\end{array}$ & $\overline{8 \cdot 40}$ & $\begin{array}{l}16 \cdot 75 \\
10 \cdot 59\end{array}$ & $\begin{array}{r}24.92 \\
8.89\end{array}$ & $\begin{array}{l}34 \cdot 34 \pm 29 \cdot 8 \\
14 \cdot 20 \pm 7 \cdot 98\end{array}$ \\
\hline
\end{tabular}

Total protein was determined by a modified biuret method (Kingsley, 1939) using versatol standards. Glucose was analysed by the glucose oxidase and peroxidase method (Bergmeyer, 1965). 
Two animals were successfully cannulated and oviduct fluid was collected for three oestrous cycles each. As reported in sheep (Restall, 1966; Black, Duby \& Reisen, 1963; Perkins, Goode, Wilder \& Henson, 1965), a cyclic variation in the secretory activity of the oviduct in both animals was observed (Table 1). Maximum secretion occurred under the influence of endogenous oestrogen and daily secretions were considerably less under the influence of endogenous progesterone. Although considerable variation occurred between the two animals, maximum secretion was observed on the 1st or on the 2nd day of oestrus. Changes were also noted with respect to total protein and total glucose (Table 2).

Volume changes during the oestrous cycle were significant (Table 1). Changes in the concentration of various constituents were insignificant $(P>$ 0.05 ), except in the case of $\mu \mathrm{g}$ of glucose $/ \mathrm{ml}$ in animal No. 239. In this animal, highly significant changes $(P<0 \cdot 01)$ were also noted with respect to total protein and total glucose. The mean values for both animals with respect to the period of oestrus and item analysed are summarized in Table 2.

In contrast to the report by Olds \& VanDemark (1957b), a cyclic secretory pattern was observed in both animals. Protein and glucose were found to be present in the oviduct secretions. The amount present per unit of volume remained essentially unchanged during the periods of the cycle, except in the case of glucose in one animal; in this case, a peak was observed during the +1 period. Because of the increase in volume during oestrus, these substrates are available in larger amounts at this time. This accounts for the significant changes in total substrate during the periods of the oestrous cycle. Animal No. 177 , which was a heifer, evidently did not have a large enough secretion volume for this effect to be noticed. The increase in secretion volume during oestrus suggests that oviduct secretion in the cow is under the control of oestrogen.

This work was supported in part by United States Public Health Grant HD 00745 and Northeastern Regional Research Project NE-41 'Endocrine Factors Affecting Reproduction in the Bovine Female'. The authors wish to acknowledge the assistance of Miss Donna Delahanty, Mr Walter Garey and Mr Daniel Sharp.

\section{REFERENCES}

Austin, C. R. (1951) Observations on the penetration of the sperm into the mammalian egg. Aust. $\mathcal{F}$. scient. Res. B4, 581.

Bergmeyer, H. (1965) Methods of enzymatic analysis. Academic Press, New York.

Brshop, D. W. (1961) Biology of spermato zoa. In: Sex and Internal Secretions, p. 707. Ed. William C. Young. Williams \& Wilkins, Baltimore.

BlAck, D. L., DuBy, R. T. \& REISEN, J. (1963) Apparatus for the continuous collection of sheep oviduct fluid. F. Reprod. Fert. 6, 257.

Blandau, R., Jensen, L. \& Rumery, R. (1958) Determination of the $\mathrm{pH}$ values of the reproductive tract fluids of the rat during heat. Fert. Steril. 9, 207.

Chang, M. C. (1951) Development of fertilizing capacity of spermatozoa deposited into the Fallopian tubes. Nature, Lond. 168, 697.

Clewe, T. H. \& Mastrolanni, L. (1960) A method for continuous volumetric collection of oviduct secretion. 7. Reprod. Fert. $1,146$.

HEAP, R. G. (1962) Some chemical constituents of uterine washings: A method of analysis with results from various species. F. Endocr. 24, 367. 
Kingsley, G. R. (1939) Determination of total serum protein, albumin, and globulin by the biuret reaction. F. biol. Chem. 131, 197.

Olds, D. \& VanDemark, N. L. (1957a) The behavior of spermatozoa in luminal fluids of bovine female genitalia. Am. F. vet. Res. 18, 603.

Olds, D. \& VanDemark, N. L. (1957b) Composition of luminal fluids in bovine female genitalia. Fert. Steril. 8, 345.

Perkins, J. L., Goode, L., Wilder, W. A., Jr \& Hensen, D. B. (1965) Collection of secretions from the oviduct and uterus of the ewe. 7. Anim. Sci. 24, 383.

Restall, B. J. (1966) The Fallopian tube of the sheep. II. The influence of progesterone and oestrogen on the secretory activities of the Fallopian tube. Aust. F. biol. Sci. 19, 181.

VanDemark, N. L. (1958) Spermatozoa in the female genital tract. Int. F. Fert. 3, 220. 